\title{
ANALISIS KUALITAS PELAYANAN ANTENATAL OLEH BIDAN
}

\author{
Annisa Andriyani ${ }^{1, *}$, Indarwati ${ }^{2}$, Tri Yuniarti ${ }^{3}$ \\ ${ }^{1,2}$ Sekolah Tinggi Ilmu Kesehatan 'Aisyiyah Surakarta \\ ${ }^{3}$ Sekolah Tinggi Ilmu Kesehatan Mambaul Ulum Surakarta \\ ${ }^{1}$ annisa7117@gmail.com*
}

\begin{abstract}
Abstrak
Latar Belakang : Kualitas pelayanan ibu di Kabupaten Sukoharjo pada tahun 2012 ditunjukkan dengan data K1 sebesar 101,4 \%, K4 sebesar 95,9 \%, FE1 sebesar 100,59 \% dan cakupan TT2 di Kabupaten Sukoharjo sangat bagus 208,07 $\%$ serta bumil resti yang ditangani sebesar 85,56 \%. Namun demikian AK1 dikabupaten ini sebesar 9 selama tahun 2012.

Tujuan : Mendiskripsikan karakteristik bidan diwilayah kerja Puskesmas Kartasura Kabupaten Sukoharjo menganalisa kompetensi teknik bidan di wilayah Puskesmas Kartasura kabupaten Sukoharjo dan menganalisa sarana dan prasarana dalam pelayanan ANC di wilayah kerja Puskesmas Kartasura, Kabupaten Sukoharjo.

Metode penelitian : Diskriptif dengan pendekatan kualitatif dan observasi langsung tentang teknis pelayanan ANC dengan system acak kepada bidan di wilayah Kartasura tanpa diketahui oleh subyek penelitian.

Hasil penelitian : Keberadaan SOP sebenarnya sudah ada. 2) Bidan sudah tahu tujuan dan manfaat SOP pelayanan antenatal care. 3) bidan belum melakukan langkah-langkah pelayanan antenatal dengan benar sesuai standart yang telah ada. 4) Kendala dalam pelayanan antenatal seperti sarana prasarana, pengetahuan, managemen waktu. 5) Belum patuh terhadap standar yang ditetapkan. Hasil observasi teknik pelayanan antenatal care $100 \%$ yang tidak dilaksanakan yaitu pemeriksaan panggul, genetalia, kepala,rambut, leher, dada, LILA, Leopod I 42,9\%, Leopod 3 dan 4 33,3\%. Temu wicara komprhensif 9,5\%. Udema kaki 23,8 $\%$, reflekpattela 33,3\% Tinggi badan $23,8 \%$ dan pemberian Fe oleh bidan secara benar $38 \%$.
\end{abstract}

Simpulan : Pelayanan antenatal belum memenuhi standart.

Kata kunci :Kualitas; ANC; Bidan

ANALISIS QUALITY OF ANTENATAL SERVICES BY MIDWIFE

\begin{abstract}
Introduction: The quality of maternal services in Sukoharjo Regency in 2012 was shown with K1 data of $101.4 \%$, K4 of $95.9 \%$, FE1 of $100.59 \%$ and TT2 coverage in Sukoharjo District very good $208.07 \%$ and resti pregnant women handled at 85.56\%. However, the AK1 in this district amounted to 9 during 2012.

Goal : To describe the characteristics of midwives in the Kartasura Puskesmas work area, Sukoharjo regency, analyze the technical competence of midwives in the Kartasura Puskesmas area, Sukoharjo regency and analyze the facilities and infrastructure in ANC services in the Kartasura Puskesmas work area, Sukoharjo regency.
\end{abstract}


Research methods: Descriptive with a qualitative approach and direct observation of the ANC technical services with a random system to midwives in the Kartasura region without being known by the research subjects.

Research results: There is SOPs actually already exists. 2) Midwives already know the purpose and benefits of SOP for antenatal care services. 3) midwives have not taken antenatal care steps correctly according to existing standards. 4) Constraints in antenatal services such as infrastructure, knowledge, time management. 5) Not compliant with established standards. The results of observations of $100 \%$ antenatal care service techniques that were not carried out were pelvic, genetal, head, hair, neck, chest examination, LILA, Leopod I 42.9\%, Leopod 3 and 4 33.3\%. 9.5\% comprehensive meeting. Foot udema 23.8\%, reflexes $33.3 \%$ Height $23.8 \%$ and correct administration of Fe by midwives $38 \%$.

Conclosion : Antenatal services do not meet the stanndart.

Keywords: Quality; ANC; Midwife

\section{PENDAHULUAN}

AKI di propinsi Jawa tengah berdasarkan laporan dari kabupaten/kota sebesar 116,34 per 100.000 kelahiran hidup pada tahun 2012. Data ini meningkat dibandingkan tahun 2011 dimana AKI sebesar 116,01 per 100.000 kelahiran hidup.

Untuk Kabupaten Sukoharjo data pada tahun 2012 kualitas palayanan ibu dikatakan berkualitas ini ditunjukkan dengan data K1 sebesar 101,4 \%, K4 sebesar 95,9 \%, FE1 sebesar 100,59 \% dan FE3 juga sebesar 100,59 \%. Sedangkan cakupan TT2+ kabupaten sukoharjo sangat bagus 208,07 \% dan bumil resti yang ditangani sebesar 85,56\%. Namun demikian AKI di kabupaten ini sebesar 9 selama tahun 2012.

Dari gambaran data diatas walaupun semua sudah baik namun perlu ditingkatkan lagi mengenai mutu layanan kebidanan terutama Antenatal care (ANC). Untuk menilai mutu layanan diperlukan standart dan indikator dimana Purwoastuti (2016) membagi menjadi empat jenis standart yaitu 1)Standart masukan(input) yang antara lain terdiri dari standart SDM, peralatan dan sarana, 2) Standart proses/standart tindakan dimana ditetapkan tata cara/prosedur pelayanan medis maupun non medis. 3) Standart keluaran /standart penampilan berdasarkan serangkaian indicator baik dari segi pemberi pelayanan maupun pemakai dan 4) Standart lingkungan/organisasi ditetapkan garis-garis besar kebijakan, pola organisasi dan manejemen yang harus dipatuhi oleh pemberi layanan.

Berdasarkan masalah - masalah yang didapatkan pada data tersebut diatas maka penulis merasa tertarik untuk meneliti tentang analisis kualitas pelayanan antenatal oleh bidan di wilayah Puskesmas Kartasura Kabupaten Sukoharjo.

\section{Pendekatan dan jenis penelitan}

\section{METODE}

Moleong (2017) mengatakan yang dimaksud dengan penelitian kualitatif adalah "tradisi tertentu dalam ilmu ngetahuan sosial yang secara fundamental bergantung 
pada pengamatan pada manusia pada kawasannya sendiri, dan berhubungan dengan orang-orang tersebut dalam bahasanya dan peristilahannya".Metode kualitatif adalah metode penelitian yang digunakan untuk meneliti pada kondisi obyek yang alamiah, di mana peneliti adalah sebagai instrument kunci, teknik pengumpulan data dilakukan secara gabungan, analisis data bersifat induktif, dan hasil penelitian kualitatif lebih menekankan makna dari pada generalisasi.

Adapun jenis penelitian ini adalah penelitian deskriptif. bahwa metode deskriptif adalah pencarian fakta dengan interpretasi yang tepat. Penelitian deskriptif mempelajari masalah-masalah dalam masyarakat, serta tata cara yang berlaku dalam masyarakat serta situasi-situasi tertentu, termasuk tentang hubunganhubungan, kegiatan-kegiatan, sikap-sikap, pandangan-pandangan, serta prosesproses yang sedang berlansung dan pengaruh-pengaruh dari suatu fenomena.

\section{Kehadiran penelitian}

Dalam penelitian ini, peneliti bertindak sebagai pengumpul data dan sebagai instrument aktif dalam upaya mengumpulkan data-data di lapangan.sedangkan instrument pengumpulan data yang lain selain manusia adalah berbagai bentuk alat-alat bantu dan berupa dokumen-dokumen lainnya yang dapat digunakan untuk menunjang keabsahan hasil penelitian, namun berfungsi sebagai instrument pendukung. Oleh karena itu, kehadiran peneliti secara langsung di lapangan sebagai tolak ukur keberhasilan untuk memahami kasus yang diteliti, sehingga keterlibatan peneliti secara langsung dan aktif dengan informan dan atau sumber data lainnya di sini mutlak diperlukan.

\section{Teknik pengumpulan data}

Pengumpulan data merupakan langkah yang sangat penting dalam penelitian, karena itu seorang peneliti harus terampil dalam mengumpulkan data agar mendapatkan data yang valid.Pengumpulan data adalah prosedur yang sistematis dan standar untuk memperoleh data yang diperlukan.

Observasi langsung adalah cara pengambilan data dengan menggunakan mata tanpa ada pertolongan alat standar lain untuk keperluan tersebut. Dalam kegiatan sehari-hari, kita selalu menggunakan mata untuk mengamati sesuatu. Observasi ini digunakan untuk penelitian yang telah direncanakan secara sistematik tentang ketrampilan bidan dalam ANC dan kepatuhan terhadap SOP. Tujuan menggunakan metode ini untuk mencatat hal-hal, perilaku, perkembangan, dan sebagainya tentang proses ANC, sewaktu kejadian tersebut berlaku sehingga tidak menggantungkan data dari ingatan seseorang. Observasi lansung juga dapat memperoleh data dari subjek baik yang tidak dapat berkomunikasi secara verbal atau yang tak mau berkomunikasi secara verbal.Pengumpulan data observasi dilakukan dengan menggunakan pedoman observasi/chek list sesuai standart.

Wawancara adalah proses memperoleh keterangan untuk tujuan penelitian dengan cara tanya jawab, sambil bertatap muka antara si penanya dengan si penjawab dengan menggunakan alat yang dinamakan interview guide (panduan wawancara).Tujuan penulis menggunakan metode ini, untuk memperoleh data secara jelas dan kongkret tentang Kebijakan program ANC dari kepala puskesmas maupun Kasi KIA puskesmas.Sedangkan sebagai pelengkap data yang lain wawancara juga dilakukan kepada pasien dan bidan. 
Dokumentasi adalah setiap bahan berupa karangan, foto,gambar, memo, pengumuman, instruksi, majalah, buletin, pernyataan, aturan suatu lembaga masyarakat, dan berita yang disiarkan kepada media massa. Dari uraian di atas maka metode dokumentasi adalah pengumpulan data dengan meneliti catatancatatan penting yang sangat erat hubungannya dengan obyek penelitian. Tujuan digunakan metode ini untuk memperoleh data secara jelas dan konkret kualitas ANC

\section{Analisis data}

Analisis data adalah proses mengorganisasikan dan mengurutkan data kedalam pola, kategori, dan satuan uraian dasar sehingga dapat ditemukan tema dan dapat dirumuskan hipotesis kerja seperti yang disarankan oleh data.

Dari rumusan di atas dapatlah kita tanarik garis besar bahwa analisis data bermaksud pertama-tama mengorganisasikan data. Data yang terkumpul banyak sekali dan terdiri dari catatan lapangan, komentar peneliti, gambar, foto, dokumen berupa laporan, biografi, artikel, dan sebagainya.Setelah data dari lapangan terkumpul dengan menggunakan metode pengumpulan data di atas, maka peneliti akan mengolah dan menganalisis data tersebut dengan menggunakan analisis secara deskriptif-kualitatif, tanpa menggunakan teknik kuantitatif.

Analisis deskriptif-kualitatif merupakan suatu tehnik yang menggambarkan dan menginterpretasikan arti data-data yang telah terkumpul dengan memberikan perhatian dan merekam sebanyak mungkin aspek situasi yang diteliti pada saat itu, sehingga memperoleh gambaran secara umum dan menyeluruh tentang keadaan sebenarnya. Tujuan deskriptif ini adalah untuk membuat deskripsi, gambaran atau lukisan secara sistematis, faktual dan akurat mengenai fakta-fakta, sifat-sifat serta hubungan antar fenomena yang diselidiki.

\section{Pengecekan keabsahan temuan}

Menurut Moleong (2017) 'kriteria keabsahan data ada empat macam yaitu :

1. Kepercayaan (kreadibility)

Kreadibilitas data dimaksudkan untuk membuktikan data yang berhasil dikumpulkan sesuai dengan sebenarnya.ada beberapa teknik untuk mencapai kreadibilitas ialah teknik : teknik triangulasi, sumber, pengecekan anggota, perpanjangan kehadiran peneliti dilapangan, diskusi teman sejawat, dan pengecekan kecakupan refrensi.

2. Kebergantungan (depandibility)

Kriteria ini digunakan untuk menjaga kehati-hatian akan terjadinya kemungkinan kesalahan dalam mengumpulkan dan menginterprestasikan data sehingga data dapat dipertanggungjawabkan secara ilmiah. Kesalahan sering dilakukan oleh manusia itu sendiri terutama peneliti karena keterbatasan pengalaman, waktu, pengetahuan. Cara untuk menetapkan bahwa proses penelitian dapat dipertanggungjawabkan melalui audit dipendability oleh ouditor independent oleh dosen pembimbing.

3. Kepastian (konfermability)

Kriteria ini digunakan untuk menilai hasil penelitian yang dilakukan dengan cara mengecek data dan informasi serta interpretasi hasil penelitian yang didukung oleh materi yang ada pada pelacakan audit. 


\section{HASIL DAN PEMBAHASAN}

Pada penelitian kali ini peneliti menggunakan rancangan kualitatif yang disajikan secara diskriftif. Data penelitian diambil dengan cara wawancara dan observasi langsung.. Hingga akhir penelitian ini telah dilakukan wawancara dengan 5 bidan dan 2 kasi KIA di layanan kesehatan. Dan observasi dengan 21 bidan di wilayah kerja puskesmas Kartasura. Hasil penelitian dan pembahasan akan diuraikan secara lengkap pada bab ini.

\section{Gambaran Umum Program Pelayanan Antenatal di Puskesmas Kartasura Kabupaten Sukoharjo}

Pelayanan kesehatan yang diberikan kepada ibu selama masa kehamilannya sesuai dengan standart pelayanan antenatal yang mencakup anamnesis pemeriksaan fisik umum dan kebidanan, pemeriksaan laboratorium, penyuluhan dan KIE.

Pelayanan antenatal dilaksanakan secara rutin selama kehamilan sebagai upaya deteksi dini kehamilan dan persalainan yang beresiko tinggi dan segera mendapatkan tindakan yang tepat untuk mengatasi.Kegiatan ini dilaksanakan minimal 4 kali selama kehamilan. Selain anamnesis dan pemeriksaan fisik secara umum penerapan operasional dikenal standar minimal (7T) yang terdiri atas :

1. (Timbang) berat badan, pengukuran tinggi badan dan pengukuran Lingkar lengan atas.

2. Ukur ( tekanan ) darah

3. Ukur (Tinggi) Fundus uteri

4. (Tetanus toxoid) Lengkap

5. Pemberian zat besi minimal 90 tablet selama hamil.

6. Tes laboratorium

7. (Temu) wicara

Puskesmas Kartasura dimana wilayah sangat luas dan beragamnya layanan kesehatan yang melaksanakan layanan antenatal telah melakukan upaya dalam meningkatkan kualitas pelayanan antenatal diantaranyanya adanya SOP pelayanan antenatal, Mengadakan pemantauan dengan pelaporan dari semua layanan antenatal di wilayah Puskesmas Kartasura.

\section{Gambaran karakteristik informan}

Dari diskripsi karakteristik responden dapat diketahui bahwa informan berumur antara 24 tahun sampai 40 tahun. Berdasarkan pendidikan semua informan berlatar belakang Diploma 3 kebidanan. Dan masa kerja informan anatara 2 tahun sampai 20 tahun.

Hasil wawancara tentang keberadaan SOP tentang layanan antenatal dan kesesuaian dengan SOP pemerintah

SOP (Standart Operasional Prosedur) tentang layanan antenatal telah ada di semua layanan. Hal ini sesuai dengan pernyataan salah satu informan yaitu

Ada bu SOP nya, dulu pernah disosialisasikan, ning yoo wis lali kita ngerjakan rutinitas sesuai kebiasaan sehari-hari

Kemarin ada ditempel di ruangan ini tetapi kemaren ada pembenahan jadi dilepas belum sempat untuk menempelkan kembali bu.... 
Berdasarkan hasil wawancara yang telah dilakukan pada 3 informan kunci menunjukkan bahwa sudah ada SOP layanan antennal sedangkan untuk sosialisasi telah dilakukan secara baik Hal ini sesuai dengan hasil trianggulasi dengan kepala KIA salah satu layanan tingkat pertama yang menyatakan.

Keberadaan SOP sebenarnya sudah ada namun demikian belum disertai penerapan di kenyataan kerja sehari-hari sehingga SOP hanya sekedar dibuat di pajang tanpa diikuti standart yang harus dilakukan.

Hasil wawancara tentang pengetahuan bidan tentang pedoman pelayanan Antenatal.

Pengetahuan bidan terkait dengan SOP layanan ANC pada penelitian ini dibedakan atas pengetahuan tentang tujuan keberadaan SOP ANC dan Pengetahuan tentang manfaat SOP ANC.

Berikut penggalan hasil wawancara peneliti dengan salah satu informan kunci :

SOP itu kan dipakai salah satu pedoman bidan dalam melakukan layanan ANC agar selalu urut kan bu....biar macam langkahnya tidak tertinggal.....jadi semua langkah bisa urut dilakukan....gitukan bu.....?

Hasil wawancara dengan ke tiga informan kunci ersebut membuktikan bahwa pada prinsipnya bidan sudah tahu tujuan dari SOP ANC yaitu mempermudah memberikan layanan pemeriksaan ibu hamil secara urut dan tertib sehingga seluruh langkah pelayanan dapat terlaksana dengan baik.

Adapun tujuan dari penyusunan SOP diantaranya agar petugas atau pegawai menjaga konsisten dan tingkat kinerja petugas atau pegawai atau tim dalam organisasi atau unit kerja, agar mengetahui dengan jelas peran dan fungsi tiap-tiap posisi dalam organisasi, memperjelas alur tugas, wewenang dan tanggung jawab dari petugas atau pegawai terkait, melindungi organisasi atau unit kerja dan petugas atau pegawai dari malpraktek atau kesalahan administrasi lainnya, untuk menghindari kegagalan atau kesalahan, keraguan, duplikasi dan inefisiensi, dan memberikan keterangan tentang dokumen-dokumen yang dibutuhkan.

Terkait dengan manfaat adanya SOP pelayanan pemeriksaan ibu hamil, beberapa informan kunci menjelaskan bahwa manfaat SOP adalah agar bidan secara hukum terlindungi jika ada pasien atau masyarakat yang komplen terhadap bidan tentang tindakan yang dilakukannya. Dan agar bidan dalam memberikan layanan sesuai dengan standart yang telah ditetapkan oleh pemerintah. Untuk lebih jelasnya berikut peneliti paparkan hasil wawancara dengan salah satu informan kunci yaitu

Resiko tinggi ibu dan janin bisa terdeksi lebih dini apabila SOP selalu dilakukan dengan benar, continue mungkin itu kali manfaat adanya SOP. Bisa juga .....SOP berguna biar sama layanan bidan kalau tempat a dilakukan leopod tempat b juga dilakukan leopod ben seragam gitu yaaa..... 
Manfaat adanya SOP yaitu melindungi tanggung gugat dari klien karena bidan telah bekerja menurut standar,dalam bekerja bidan selalu menjaga kualitasnya sesuai standart yang ada, dan hasil akhirnya ibu dan janin dapat terpantau dengan baik. Dapat disimpulkan bahwa bidan mempunyai wawasan yang baik tentang manfaat dari SOP pelayanan antenat yang telah dibuat (Hartatik 2014)

Manfaat yang didapat dengan pembuat SOP diantaranya : efisiensi waktu. memudahkan tahapan pelayanan yang diberikan kepada, sarana untuk mengkomunikasikan pelaksanaan suatu pekerjaan, acuan dalam melakukan penilaian terhadap proses layanan, sarana mengendalikan dan mengantisipasi apabila terdapat suatu perubahan sistem, dapat digunakan sebagai daftar yang digunakan secara berkala oleh pengawas ketika diadakan audit.(Tambunan 2011)

\section{Hasil wawancara tentang langkah-langkah pelayanan antenatal yang dilakukan bidan}

Setelah kita pastikan bahwa dilayanan kesehatan tersebut terdapat SOP pelayanan antenatal. Bidan mengetahui tujuan dan manfaatnya. Maka peneliti ingin mengetahui langkah pelayanan antenatal yang dilakukan oleh bidan. Untuk lebih jelasnya mari kita simak hasil wawancara dengan salah satu informan kunci yang telah kami wawancarai

Yaa pertama yooo mesti cucitangan bu....tanya-tanya identitas dan riwayat trus nimbang tensi , pemeriksaan fisik mata dan payudara, periksa leopod,DJJ, kasih obat jelaskan sedikit sudah..........

Dari hasil wawancara dengan 3 informan dapat disimpulkan bahwa bidan belum melakukan langkah-langkah pelayanan antennal dengan benar sesuai standart yang telah ada. Pemeriksaan atau layanan antenatal dilaksanakan secara rutinitas tanpa acuhan standart baku dari layanan antenatal.

Terkait dengan SOP yang telah dibuat sebaiknya setiap layanan memasang sop didinding sehingga setiap melaksanakan pelayanan antennal selalu ingat dan sesuai dengan standar

\section{Hasil wawancara kepatuhan bidan dalan pelayanan antenatal}

Yang dikatakan patuh apabila bidan melaksanakan pelayanan antennal sesuai dengan standar baik urutan, komponen dan benar cara melakukannya.Dari wawancara dengan salah satu informan kunci yang telah kami lakukan dengan hasil.

Jujur bu belum patuh saya...... memeriksa yaa sesuai kebutuhan saja, seperti cuci tangan yoo pisan tok kalau mau periksa pertama sokyoo lali apalagi setelah tindakan, pemeriksaan fisik dilihat kalau tidak pucet yaa ndak usah diperiksa mata dan hbnya, kalau kira-kira tinggi yaa tidak usah periksa TB, apalagi panggul : jangka saja tidak punya.

Ketiga informan menyatakan belum patuh terhadap standar yang telah ditetapkan, dari hasil wawancara tersebut ketidakpatuhan disebabkan terlalu lama apabila semuanya diperiksa sehingga bidan hanya memeriksa yang sekiranya senjang dan diperlukan. 
Namun demikian menurut Utarini et. al. suatu pernyataan yang dapat dipergunakan untuk mengukur atau menilai efektifitasnya suatu sistem layanan. Dan menurut Meissenheimer dalam Koenjoro menyatakan ukuran yang ditetapkan dan disepakati bersama, merupakan tingkat kinerja yang diharapkan. UU no 23 tahun 1992 pasal 2 disebutkan bahwa standart merupakan pedoman yang harus digunakan sebagai petunjuk dalam menjalankan profesi dengan baik( Koenjoro, 2011)

Faktor yang mempengaruhi kepatuhan adalah pengetahuan bidan, dalam hal ini bidan telah memiliki pengetahuan yang baik ditunjukkan bidan telah tahu manfaat dan tujuan dari standart SOP yang telah ada. Hal ini sesuai dengan penelitian dari Rostiati (2011) bahwa bidan memiliki pengetahuan yang baik. Namun demikian dari hasil penelitian ini nilai kepatuhan bidan dalam melaksanakan SOP dikatakan belum patuh hal ini sesuai penelitian dari Wundashari (2013) yang mengatakan bahwa semakin lengkap kemampuan pelayanan antenatal atau kurangnya kemampuan pelayanan dari penyimpangan kecil dari prosedur standart samapai kesalahan besar akan menurunkan mutu pelayanan yang di berikan. Tanujaya 2014 mengatakan bahwa ketrampilan mempengaruhi tingkat kepuasan pasien.

Jadi dapat disimpulkan dalam penelitian ini walaupun pengetahuan bidan telah baik tentang standart layanan tetapi kompetensi tehnisnya kurang baik ditandai kurang patuhnya terhadap SOP sehinggga mutu pelayanan yang ada juga belum maksimal.

\section{Hasil wawancara tentang kendala dalam melaksanakan saat melakukan layanan antenatal}

Standart layanan antenatal yang telah dibakukan memang sudah ada dan untuk melaksanakannya, ternyata dari hasil wawancara diatas menunjukan kurang patuhnya bidan dalam melakukan layanan antenatal. Pastinya ketidakpatuhan itu dilakukan karena banyak sebab atau kendala dan bukan sebagai faktaor kesengajaan. Berikut wawancara dengan salah satu informan tentang hal tersebut.

Rasanya kami sudah mematuhi SOP tetapi kalau dibaca ulang memang masih banyak kurangnya, bukan berarti kami sengaja tapi mungkin karena pelayanan antenatal merupakan kegiatan rutin yaa seperti itu-itu juga kami lakukan, seperti antrian pasien yang banyak menyebabkan kita kadang dituntut ndang cepet.......

Hasil wawancara menunjukkan adanya kendala dalam pelayanan antenatal seperti sarana prasarana, pengetahuan, menegement waktu dalam mengatur antrian pasien sehingga bidan tidak tergesa-gesa dalam melakukan tindakan. Ditemukan factor-faktor lain yang mempengaruhi persepsi pasien tentang mutu layanan yaitu hubungan interpersonal antara petugas dengan ibu hamil yang dikatagorikan kurang.

Hasil wawancara tentang Fasiltas yang digunakan dalam layanan antenatal

Secara standart alat-alat yang digunakan dalam layanan antenatal yaitu tensimeter, pengukur berat badan, pengukur tinggi badan, Stestoskop, fetoskop, reflek hammer, hb meter, metlin, pengukur lila, jangka panggul, termometer, 
senter. Dari hasil wawancara yang peneliti lakukan pada salah satu informan didapatkan hasil sebagai berikut

Untuk alat yang digunakan disini ada semua puskesmas telah menyediakan yang tidak ada hanya jangka panggul bu memang selama saya jadi bidan mengukur panggul yaa pas ujian itu...... setelah itu tidak pernah

Wawancara dengan informan kunci menunjukkan bahwa semua alat sudah ada tapi yang tidak ada adalah jangka panggul untuk alat yang lain bisa dilengkapi sendiri oleh layanan antenatal tersebut.

\section{Hasil Observasi persiapan penolong : cuci tangan sebelum dan sesudah tindakan}

Sebelum dan sesudah melaksanakan suatu tindakan seorang tenaga kesehatan diwajibkan untuk cuci tangan sebagai tindakan perlindungan diri dari infeksi dan tindakan pencegahan nosokomial.

Tabel 1. Kepatuhan Persiapan penolong : cuci tangan sebelum dan sesudah

\begin{tabular}{cccc}
\multicolumn{3}{c}{ tindakan } \\
\hline No & Cuci tangan & Jumlah & presentase \\
\hline 1 & Dikerjakan & 3 & $14,3 \%$ \\
2 & Tidak dikerjakan & 18 & $85,7 \%$ \\
& Total & 21 & $100 \%$ \\
\hline
\end{tabular}

Dari data diatas $85,7 \%$ tidak melaksanakan tindakan tersebut, hal ini sesuai penelitian Ariyanti (2010) dimana 100\% respondennya tidak melakukan cuci tangan sebelum dan sesudah tindakan, hal ini disebabkan kurangnya sarana cuci tangan.

Hasil Observasi Anamnesa identitas pasien, Riwayat kehamilan, Anamnesa Riwayat persalinan, Anamnesa Riwayat penyakit

Tabel 2. Kepatuhan anamnesa identitas pasien Riwayat kehamilan, Anamnesa Riwayat persalinan, Anamnesa Riwayat penyakit

\begin{tabular}{clcc}
\hline No & Anamnesa identitas pasien & Jumlah & presentase \\
\hline 1 & Dikerjakan & 21 & $100 \%$ \\
2 & Tidak dikerjakan & 0 & $0 \%$ \\
& & 21 & $100 \%$ \\
\hline
\end{tabular}

Anamnesa identitas pasien dilakukan pada ibu hamil meliputi nama, umur, agama, pendidikan golongan darah, pekerjaan dan alamat baik ibu hamil maupun suaminya. Riwayat kehamilan yang ditanyakan dan diisikan di buku KIA adalah HPHT, Keluhan ibu, penggunaan kontrasepsi sebelum hamil ini, riwayat penyakit yang diderita sebelum hamil ini, dan riwayat alergi. Anamnesa riwayat persalinan yang harus ditanyakan adalah Gravida Para Abortus (GPA), jumlah anak yang hidup, jumlah anak yang mati, kapan persalinan terakhir,siapa penolong persalinan terakhir, cara persalinan lalu, status imunisasi TT saat ini . Anamnesa riwayat penyakit yang ditanyakan adalah riwayat penyakit yang 
diderita sebelum hamil, riwayat keturunan kembar dan riwayat alergi baik obat atau makanan (Dep Kes RI, 2010)

Dari data diatas dapat disimpulkan bahwa semua bidan telah melaksanakan anamnesa identitas pasien, anamnesa riwayat penyakit dengan baik ditunjukkan $100 \%$ responden melaksanakan kegiatan tersebut. Hal ini sesuai penelitian Ariyanti (2010), dimana anamnesa ibu hamil dilakukan semua dengan hasil $100 \%$.

Anamnesa riwayat kehamilan hasil penelitian sesuai penelitian Rostiati (2011) dimana $100 \%$ respondennya juga melakukan anamnesa riwayat kehamilan.

Anamnesa riwayat persalinan dan anamnesa riwayat pernyakit menunjukkan bahwa semua responden $100 \%$ melaksanakan anamnesa riwayat persalinan. Hal ini didukung penelitian Rostianti 2011 dan Ariyanti 2010 dimana semua responden telah melakukan anamnesa sebesar $100 \%$. Keadaan sangat baik dan perlu dipertahanan untuk mencapai kualitas layanan yang baik.

\section{Hasil Observasi Pelaksanaan mengukur tinggi badan}

Tinggi badan ibu hamil adalah perhatian awal seorang bidan tentang bagaimana keadaan tulang panggul seorang ibu hamil tersebut. Seorang ibu hamil yang tinggi badannya $145 \mathrm{~cm}$ atau kurang, akan mendapat catatan khusus dari tenaga kesehatan karena kemungkinan mengalami panggul sempit lebih besar. Ibu hamil yang pendek termasuk kelompok berisiko tinggi, walaupun demikian semua kehamilan sebenarnya tetap mendapat perhatian sama dan dianggap berisiko.

Tabel 3. Kepatuhan pelaksanaan mengukur tinggi badan

\begin{tabular}{cccc}
\hline No & Mengukur tinggi badan & Jumlah & presentase \\
\hline 1 & Dikerjakan & 5 & $23,8 \%$ \\
2 & Tidak dikerjakan & 16 & $76,2 \%$ \\
& Total & 21 & $100 \%$ \\
\hline
\end{tabular}

Data table 3 menunjukkan hanya 23,8 \% bidan yang melaksanakan pengukuran tinggi badan. Hal ini sangat disayangkan sekali dimana Tinggi Badan merupakan satu indicator bahwa ibu hamil mengalami panggul sempit atau tidak sehingga bisa ditentukan jenis persalinan yang aklan dilakukan nantinya. Berbeda dengan penelitian Rostianti dimana pemeriksaan fisik dilakukan $100 \%$ perbedaan tersebut dikarenakan cara pengambilan sampel yang berbeda dengan penelitian yang sedang dilakukan saat ini.

\section{Hasil Observasi Pelaksanaan mengukur berat badan}

Tabel 4. Kepatuhan pelaksanaan mengukur berat badan

\begin{tabular}{cccc}
\hline No & Mengukur berat badan & Jumlah & presentase \\
\hline 1 & Dikerjakan & 20 & $95,3 \%$ \\
2 & Tidak dikerjakan & 1 & $4.7 \%$ \\
& Total & 21 & $100 \%$ \\
\hline
\end{tabular}

Data table 4 menunjukkan bahwa hampir semua responden melakasanakan mengukuran berat badan ibu hamil. Pertambahan berat badan ibu selama kehamilan dapat digunakan sebagai indikator pertumbuhan janin dalam rahim. Berdasarkan pengamatan pertambahan berat badan ibu selama kehamilan dipengaruhi berat badannya sebelum hamil . Pertambahan yang optimal adalah 
kira-kira $20 \%$ dari berat badan ibu sebelum hamil, jika berat badan tidak bertambah, menunjukkan ibu mengalami kurang gizi.

\section{Hasil Observasi Pelaksanaan mengukur LILA}

Tabel 5. Kepatuhan pelaksanaan mengukur LILA

\begin{tabular}{cccc}
\hline No & Mengukur LILA & Jumlah & presentase \\
\hline 1 & Dikerjakan & 0 & $0 \%$ \\
2 & Tidak dikerjakan & 21 & $100 \%$ \\
& Total & 21 & $100 \%$ \\
\hline
\end{tabular}

Pada tabel diatas menunjukkan bahwa semua bidan tidak melaksanakan pengukuran lila. Penelitihan ini didukung olen penelitian ariyanti dimana hasil nilai pemeriksaan fisik hanya $60,69 \%$.

Seharusnya pengukuran LILA dilakukan pasti ada fungsinya yaitu untuk mengetahui status gizi ibu hamil. Status gizi ibu hamil akan berpengaruh terhadap bayi yang akan dilahirkannya.

\section{Hasil Observasi Pelaksanaan mengukur tekanan darah}

Tabel 6. Kepatuhan pelaksanaan mengukur tekanan darah

\begin{tabular}{cccc}
\hline No & Mengukur tekanan darah & Jumlah & presentase \\
\hline 1 & Dikerjakan & 21 & $100 \%$ \\
2 & Tidak dikerjakan & 0 & $0 \%$ \\
& Total & 21 & $100 \%$ \\
\hline
\end{tabular}

Data table 6 menunjukkan bahwa semua responden $100 \%$ melaksanakanpengukuran tekanan darah. Hal ini didukung penelitian Rostianti 2011 dan Ariyanti 2010 dimana semua responden telah melakukan anamnesa sebesar $100 \%$. Keadaan sangat baik dan perlu dipertahanan untuk mencapai kualitas layanan yang baik.

Kenaikan tekanan darah dan tekanan diastolik yang mencapai >140/90 $\mathrm{mmHg}$ atau mengalami kenaikan $15 \mathrm{mmHg}$ dalam 2 kali pengukuran dengan jarak 1 jam, ibu hamil dikatakan preeklamsi mempunyai dari 3 gejala preeklamsi. Apabila preeklamsi tidak dapat diatasi, maka akan berlanjut menjadi eklamsi. Dimana eklamsi salah satu faktor penyebab utama terjadinya kematian maternal (Raghupathy . 2013)

\section{Hasil Observasi Pelaksanaan imunisasi TT}

Tabel 7. Kepatuhan pelaksanaan imunisasi TT

\begin{tabular}{cccc}
\hline No & Pelaksanaan imunisasi TT & Jumlah & presentase \\
\hline 1 & Dikerjakan & 7 & $33,3 \%$ \\
2 & Tidak dikerjakan & 14 & $66,7 \%$ \\
& Total & 21 & $100 \%$ \\
\hline
\end{tabular}

Pelaksanaan imunisasi TT sering terlewatkan karena masih terjadi perbedaan pemberian imunisasi TT pada ibu hamil . Pelaksanaan TT bisa tidak dilakukan apabila mengaju pada table di buku KIA, sehingga dapat disimpulkan bahwa pemberian TT dilakukan sesuai status TT ibu, tidak setiap hamil harus dilaksanakan suntik TT. 


\section{Hasil Observasi Pelaksanaan pemberian tablet fe}

Tabel 8. Kepatuhan pelaksanaan pemberian tablet fe

\begin{tabular}{cccc}
\hline No & Pemberian tablet fe & Jumlah & presentase \\
\hline 1 & Dikerjakan & 8 & $38 \%$ \\
2 & Tidak dikerjakan & 13 & $62 \%$ \\
& Total & 21 & $100 \%$ \\
\hline
\end{tabular}

Data diatas menunjukkan bahwa pemberian Fe oleh bidan secara benar hanya $38 \%$ dari responden yang ada. Kualitas pemberian Fe tidak hanya sekedar diberikan obat sejumlah 90 tablet saja, namum bagaimana cara meminumnya, evaluasi Fe yang kemarin. Ada beberapa layanan pemberian Fe diberikan oleh petugas ruang obat tanpa konseling yang benar untuk meminum Fe. Sedang teori Surdjaja (2010) mengatakan Ibu hamil yang mendapatkan zat besi sebanyak 95 orang $(100 \%)$ dan ibu hamil yang tidak mendapatkan tablet besi sesuai standar yaitu 30 butir setiap triwulan. Hal ini dikarenakan petugas kesehatan memberikan tablet besi sebanyak 30 butir pada kunjungan K1 di setiap kunjungan berikutnya ibu hamil hanya diberi 1 bungkus tablet yang berisi 10 butir yang berkunjung 1 kali tiap trimester atau >4 kali selama kehamilan. Tidak mendapatkan zat besi minimal 30 tablet per triwulan.

\section{Hasil Observasi Pelaksanaan test laboratorium}

Tabel 9. Kepatuhan pelaksanaan test laboratorium

\begin{tabular}{cccc}
\hline No & Pelaksanaan test laboratorium & Jumlah & presentase \\
\hline 1 & Dikerjakan & 9 & $42,9 \%$ \\
2 & Tidak dikerjakan & 12 & $57,1 \%$ \\
& Total & 21 & $100 \%$ \\
\hline
\end{tabular}

Dari data diatas dapat diambil kesimpulan bahwa hanya 42,9\% bidan yang melakukan deteksi anemia dengan memeriksa HB. Sedangkan penelitian Zainap 2003 mengatakan bahwa sarana prasarana termasuk alat pemeriksaan hb telah lengkap. Perlu dikaji kembali factor-faktor penyebab kenapa tidak dilaksanakan prosedur pemeriksaan $\mathrm{Hb}$.

\section{Hasil Observasi Pelaksanaan temu wicara menjelaskan hasil pemeriksaan secara komprehensif}

Tabel 10. Kepatuhan pelaksanaan temu wicara menjelaskan hasil pemeriksaan secara komprehensif

\begin{tabular}{cccc}
\hline No & Temu wicara & Jumlah & presentase \\
\hline 1 & Dikerjakan & 2 & $9,5 \%$ \\
2 & Tidak dikerjakan & 19 & $90,5 \%$ \\
& Total & 21 & $100 \%$ \\
\hline
\end{tabular}

Temu wicara tentang penjelasan pemeriksaan dari awal hanya 9,5\% dilakukan. Biasanya bidan hanya menjelaskan hasil pemeriksaan saat itu saja tidak melihat tren apa yang terjadi sejak pemeriksaan pertama sampai pemeriksaan hari itu, sehingga bidan tidak mendapatkan diagnose yang benar dari pemeriksaan tersebut yang merupakan scerning awal adanya kelainan kehamilan. 


\section{Hasil Observasi Pelaksanaan Temu wicara KIE yang diperlukan}

Tabel 11. Kepatuhan pelaksanaan Temu wicara KIE yang diperlukan

\begin{tabular}{cccc}
\hline No & Mengukur berat badan & Jumlah & presentase \\
\hline 1 & Dikerjakan & 20 & $95,3 \%$ \\
2 & Tidak dikerjakan & 1 & $4.7 \%$ \\
& Total & 21 & $100 \%$ \\
\hline
\end{tabular}

Dari hasil table diatas dapat disimpulkan bidan melaksanakan KIE yang dibutuhkan hal ini dukung bahwa klien selalu bertanya yang dia tahu dan bidan menjawab apa yang ditanyakan pasien.

\section{Hasil Observasi Pelaksanaan fisik rambut, kepala, leher, dada}

Tabel 12. Kepatuhan pelaksanaan pemeriksaan fisik rambut, kepala, leher, dada

\begin{tabular}{cccc}
\hline No & pemeriksaan & Jumlah & presentase \\
\hline 1 & Dikerjakan & 0 & 0 \\
2 & Tidak dikerjakan & 21 & $100 \%$ \\
& Total & 21 & $100 \%$ \\
\hline
\end{tabular}

Pemeriksaan fisik dari rambut, kepala, leher dan dada sama sekali tidak ada bidan yang mengerjakan, penelitian ini bertolak belakang dengan penelitian Rostianti (2011) dimana pemeriksaan fisik dilakukan 100\%. Hal ini di karenakan cara pengambilan sampel yang berbeda.

Pemeriksaan fisik merupakan pemeriksaan awal dimana terdapat tanda dan gejala dari suatu penyakit atau penyimpangan oleh sebab itu diagnose yang tepat harus ditunjang oleh pemeriksaan yang tepat juga. Sehingga dapat dikatakan bahwa kualitas antenatal belum bagus dan deteksi dini dari komplikasui tidak akan terdiagnosa dengan benar karena data tidak tergali.

Hasil Observasi Pelaksanaan pemeriksaan Leopod

Tabel 13. Kepatuhan pelaksanaan pemeriksaan leopod 1

\begin{tabular}{cccc}
\hline No & leopod 1 & Jumlah & presentase \\
\hline 1 & Dikerjakan & 9 & $42,9 \%$ \\
2 & Tidak dikerjakan & 12 & $57,1 \%$ \\
& Total & 21 & $100 \%$ \\
\hline
\end{tabular}

Tabel 14. Kepatuhan pelaksanaan pemeriksaan leopod 2

\begin{tabular}{cccc}
\hline No & Leopod 2 & Jumlah & presentase \\
\hline 1 & Dikerjakan & 21 & $100 \%$ \\
2 & Tidak dikerjakan & 0 & $0 \%$ \\
& Total & 21 & 100 \\
\hline
\end{tabular}

Tabel 15. Kepatuhan pelaksanaan pemeriksaan leopod 3

\begin{tabular}{cccc}
\hline No & Leopod 3 & Jumlah & presentase \\
\hline 1 & Dikerjakan & 7 & $33,3 \%$ \\
2 & Tidak dikerjakan & 14 & $66,7 \%$ \\
& Total & 21 & 100 \\
\hline
\end{tabular}

Tabel 16. Kepatuhan pelaksanaan pemeriksaan leopod 4

\begin{tabular}{llll}
\hline No & leopod 4 & Jumlah & presentase \\
\hline
\end{tabular}




\begin{tabular}{lccc}
\hline 1 & Dikerjakan & 7 & $33,3 \%$ \\
2 & Tidak dikerjakan & 14 & $66,7 \%$ \\
& Total & 21 & $100 \%$ \\
\hline
\end{tabular}

Dari table diatas didapatkan pemeriksaan TFU secara benar hanya 42,9\% hal ini dikarenakan bidan menggunakan ukuran jari. Padahal penggunaan ukuran jari tidak bisa dijadikan dasar dalam penilaian perkiraan besar janin. Agar lebih tepat sebaiknya menggunakan alat centimeter yang telah terstandar sehingga dapat diukur reabilitasnya. Hal ini sesuai penelitian sholekhah at all (2016) Belum semua bidan di puskesmas kabupaten patuh terhadap protap ANC terpadu berkualitas, dan semakin patuh bidan terhadap protap ANC terpadu berkualitas, semakin terdeteksi adanya komplikasi atau penyakit yang menyertai kehamilan.

\section{Hasil Observasi Pelaksanaan pemeriksaan DJJ}

Tabel 17. Kepatuhan pelaksanaan pemeriksaan DJJ

\begin{tabular}{cccc}
\hline No & pemeriksaan DJJ & Jumlah & presentase \\
\hline 1 & Dikerjakan & 19 & $90,5 \%$ \\
2 & Tidak dikerjakan & 2 & $9,5 \%$ \\
& Total & 21 & $100 \%$ \\
\hline
\end{tabular}

Tabel di atas menjelaskan bahwa 90,5 \% bidan melaksanakan semua. Hal ini dikarenakan DJJ merupakan frekuensi denyut rata-rata wanita tidak sedang bersalin, atau diukur diantara dua kontraksi. Rentang normal adalah 120 sampai 160 denyut/menit. Bunyi denyut jantung janin,seperti bunyi detik jam dibawah bantal.

\section{Hasil Observasi Pelaksanaan pemeriksaan genetalia dan panggul luar}

Tabel 18. Kepatuhan pelaksanaan pemeriksaan genetalia dan panggul luar

\begin{tabular}{cccc}
\hline No & pemeriksaan & Jumlah & presentase \\
\hline 1 & Dikerjakan & 0 & 0 \\
2 & Tidak dikerjakan & 21 & $100 \%$ \\
& Total & 21 & $100 \%$ \\
\hline
\end{tabular}

Pemeriksaan Genetalia pada pelaksanaannya tidak pernah dilaksanakan pada hal dalam SOP jelas sekali harus dilaksanakan. Ketentuan tersebut diberikan salah satunya adalah untuk melindungi tenaga kesehatan dan pasien juga. Tujuan pada ibu hamil terutama untuk mengetahui penyakit- seperti herpes genetalia, hemoroid dan lainnya sehinggga dapat untuk menentukan diagnose untuk proses persalinan yang akan ditempuh.

Pada pemeriksaan panggul luar tidak ada bidan yang melaksanakan tindakan tersebut selain alatnya tidak ada mereka juga kurang tahu manfaat dan cara menggunakan alat tersebut hal ini sesuai penelitian Ariyanti ( 2010) dimana pemeriksaan panggul luar tudak dilaksanakan.

\section{Hasil Observasi Pelaksanaan pemeriksaan ektremitas reflek patella}

Tabel 19. Kepatuhan pelaksanaan pemeriksaan ektremitas reflek patella

\begin{tabular}{cccc}
\hline No & reflek patella & Jumlah & presentase \\
\hline 1 & Dikerjakan & 7 & $33,3 \%$ \\
\cline { 2 - 3 } & & & \\
\hline
\end{tabular}




\begin{tabular}{ll}
\hline 14 & $66,7 \%$ \\
21 & $100 \%$
\end{tabular}

Dari data diatas pemeriksaan fisik berupa reflek patella hanya 33,3\% responden yang melakukan hal ini sesuai penelitian Ariyanti (2010) dimana pemeriksaan yang tidak dilakukan salah satunya adalah reflek patella.

\section{Hasil Observasi Pelaksanaan pemeriksaan ektremitas udema kaki}

Tabel 20. Kepatuhan pelaksanaan pemeriksaan ektremitas udema kaki

\begin{tabular}{cccc}
\hline No & udema kaki & Jumlah & presentase \\
\hline 1 & Dikerjakan & 5 & $23,8 \%$ \\
2 & Tidak dikerjakan & 16 & $76,2 \%$ \\
& Total & 21 & $100 \%$ \\
\hline
\end{tabular}

Dari table 20 dapat disimpulkan bahwa hanya 23,8 \% bidan yang melaksanakan prasat tersebut secar benar. Hal ini sesuai penelitian Ariyanti (2010). Biasanya bidan hanya melihat saja tanpa melaksanakan pitting udema.

Udema kaki merupakan salah satu tanda dari pre eklamsia, dimana pre eklamsia merupakan salah satu penyebab kematian ibu saat melahirkan.

\section{SIMPULAN}

Penelitian tentang kualitas antenatal oleh bidan di wilayah Puskesmas kartasura yaitu 1) Keberadaan SOP sebenarnya sudah ada namun demikian belum disertai penerapan di kenyataan kerja sehari-hari sehingga SOP hanya sekedar dibuat di pajang tanpa diikuti standart yang harus dilakukan .2) Bidan sudah tahu tujuan dari pedoman atau SOP pelayanan antenatal care yaitu mempemudah memberikan layanan pemeriksaan ibu hamil secara urut dan tertib sehingga seluruh langkah pelayanan dapat terlaksana dengan baik. 3) Bidan belum melakukan langkah-langkah pelayanan antennal dengan benar sesuai standart yang telah ada. Pemeriksaan atau layanan antenatal dilaksanakan secara rutinitas tanpa acuhan standart baku dari layanan antenatal.4) Kendala dalam pelayanan antenatal seperti sarana prasarana, pengetahuan, menegement waktu dalam mengatur antrian pasien sehinnga bidan tidak tergesa-gesa dalam melakukan tindakan. 5) Belum patuh terhadap standar yang telah ditetapkan, dari hasil wawancara tersebut ketidakpatuhan disebabkan terlalu lama apabila semuanya diperiksa sehingga bidan hanya memeriksa yang sekiranya senjang dan diperlukan.

\section{SARAN}

Perlunya meningkatkan ilmu dan meningkatkan kesadaran tentang tugas bidan dan tanggung jawabnya sebagai pelayanan masyarakat. Demikian pula untuk dinas kesehatan perlu melakukan penyegaran dan persamaan persepsi kembali tentang standart baku pelayanan antenatal dan perlunya dilakukan monitoring dan evaluasi kepada bidan tentang pelaksanaan pelayanan antenatal . 


\section{DAFTAR PUSTAKA}

Ariyanti.D.F, 2010, Analisis kualitas Pelayanan Antenatal oleh bidan di puskesmas di kabupaten pekalongan (teis) UNDIP. Semarang.

Depkes RI .2010. kesehatan ibu dan anak. Dep.kes RI. Jakarta

Hartatik IP.2014 Buku praktis mengembangkan sdm Yogyakarta.Laksana

Koenjoro, T . 2011.Regulasi kesehatan di Indonesia Yogyakrta : Andi

Moleong.L.J.2017. Metodologi penelitian kualitatif (Edisi Revisi) PT Remaja Rosda kaya Bandung

Purwoastuti T\&Walyani ES.2016.Mutu Pelaynan Kesehatan dan Kebidanan ,Pustaka Press.Yogyakarta

Rostianti. E.2011. Evaluasi kinerja bidan puskesmas dalam pelayanan ANC di kecamatan banjarsari Surakarta. Tesis. UNS. Surakarta

Raghupathy R. 2013. Cytokines as Key Players in the Pathophysiology of Preeclampsia. Journal Medical Principles and Practice, 22 (23), 8-19.

Surjadja.2010. Asuhan kebidanan . antennal .AUP Surabaya

Sholikhah S,Pradjatmo H, Hakimi M.Kepatuhan bidan Puskesmas dalam penerapan antenatal care terpadu berkualitas, deteksi penyakit dan komplikasi pada ibu hamil Berita Kedokteran Masyarakat (BKM Journal of Community Medicine and Public Health) Volume32 Nomor 5

Tanujaya 2014 Pengaruh Kualitas Pelayanan Klinik GigiTerhadap Kepuasan Dan Kepercayaan Pasien Sehingga Meningkatkan Keinginan Untuk Berobat Kembali..Volume 7, No.1 Tahun 2014. Jurnal Manajemen Dan Pemasaran Jasa

Wundashary, darmansyah, nurhayani.2013 Analisis pelayanan antenatal care di puskesmas wonrely kabupaten Maluku barat daya propinsi Maluku. Jurnal 